\title{
OLD TESTAMENT WORD-STUDIES: 10. TIME AND ETERNITY.
}

\author{
By Rev. P. A. Nordell, D. D.,
}

New London, Conn.

While the Hebrew verbs may be said to be almost destitute of tense in the IndoEuropean sense of the word, the language itself is quite rich in terms expressing with more or less definiteness the relations of time. Only a small number of them can be considered here. For a full and satisfactory development of their relations, and comparative value in the cognate languages, see Orelli, Die Hebräischen Synonyma der Zeit und Ewigkeit, Leipzig, 1871.

$$
\text { Rë'shith first, beginning. }
$$

This word and the next are perhaps the simplest notions of time considered in relation to the present moment. $R \bar{e}^{\prime} \mathrm{sh}_{\mathrm{i}} \mathrm{th}$, from $\mathrm{ro}$ 's $\mathrm{h}$, head, is an indefinite term designating past events. It does not point to the head in contrast with the feet, but to the previous in contrast with the subsequent. "The re' $\mathrm{sh} \hat{\mathrm{ith}}$ of the first fruits," Ex. 23:19; 34:36, or of the corn and fleece, Deut. 18:4, is that which comes at the head of a series, the first in point of time. Peculiar excellence was attributed to the increase which appeared earliest, whether in the field or in the family. The first-born among the Egyptians are called "the chief, re'shith, of their strength," Ps. 78:51 ; 105:36. In Israel the first fruits of the field, as well as the first-born among the cattle or in the family were set apart as the special property of Jehovah. In the attributes of wisdom and knowledge the fear of the Lord is $\mathrm{r} \overline{\mathrm{e}}$ 'sh $\mathrm{ith}$, a thing of supreme value, and therefore to be sought before anything else, Ps. 111:10; Prov. 1:7; 4:7. Re' 's hîth almost always occurs in the construct state with a suffix or genitive of definition. The only exceptions are Gen. 1:1 and Isa. 46:10. In these instances it is not used in the sense of first, or foremost, but absolutely in the beginning, precisely as $\dot{\varepsilon} \nu \dot{a} \rho \chi \tilde{\eta}$ in John 1:1, which is unquestionably suggested by $b^{e} \mathrm{re}^{\prime} \mathrm{sh} \hat{\mathrm{ith}}$ in Gen. 1:1. Does this phrase carry the mind back merely to the beginning of the creation, or to the starting-point of human thought? As employed by John it certainly points to a pre-temporal life. It is possible that $b^{e} \mathrm{re}^{-} \mathrm{sh} \hat{\mathrm{i}} \mathrm{th}$, standing on the remotest verge of the thinkable past, really looks into an eternity which cannot be described except in terms of time and of relation.

Furthermore, it appears that when the Hebrew intended to express the thought that a thing was elementally, essentially so, he said that it was so from the beginning, e. g. "from the beginning it hath not been so," Mt. 19:8, i. e. the stability of the marriage relation reposes in the very nature of things. "He was a murderer from the beginning," John 8:44, i. e. in his central, essential character. Each of these instances has of course an historical basis, but it seems also to expand into a philosophical conception. Without projecting modern metaphysical 
notions into the simple archaic phrase b ${ }^{e} \mathrm{re}^{-} \operatorname{sh} \hat{\mathrm{ith}}{ }^{\prime}{ }^{\theta} \mathrm{l} \overline{\mathrm{o} h} \mathrm{i} \mathrm{m}$, "in the beginning -God," it may fairly be held to imply more than the starting-point of the generations of the heavens and of the earth. It seems to elude all relations of before and after, and to escape into the timelessness of the elemental and absolute Life out of which proceeded, in the very nature of the case, the world of manifestation and change.

$$
\text { 'ăhầith last, end. }
$$

, ăh ${ }^{a}$ rîth denotes the last of a series, Ps. 139:9; Amos 9:1, and from this relation to space it passes easily into a relation to time, Prov. 29:21. Joined with yāmîm in the phrase yāmîm 'a ha "rith, "the end of days," it becomes a frequent designation for an indefinite future especially characteristic of prophetic discourse, Gen. 49:1; Num. 24:14; Deut. 4:30 ; Isa. 2:2, etc. In Prov. 19:20 it stands for old age, and in Num. 23:10 for the end of life. In a sense a man may be said to live in his children after he himself has passed away; accordingly it is said that there is an ' $a h^{a}{ }^{a} \hat{i} t h$, a future, for the man of peace, but the 'a ${ }^{a}{ }^{a} \hat{i} t h$ of the wicked shall be cut off, Ps. 37:37,38.

\section{'eth time.}

This is the most frequent word for the general designation of time. Its derivation is uncertain. If that suggested by Fleischer from ' $\bar{a} n \bar{a} h$ be accepted as most probable, it would denote an entrance, a meeting, and this meaning would be supported in many of its occurrences. In common usage, therefore, it desig-

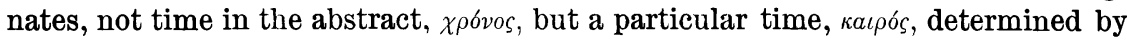
natural law, Gen. 18:10; 31:10; Lev. $26: 4$; by custom, Gen. $29: 7$, or in general by the concurrence of specific events. In Ps. 31:16 the plural, "my times," gathers up not only the details of human life, but its whole general course and destiny.

$$
\text { Mó'èdh season, appointed time. }
$$

$M \hat{o}^{\top} \overline{\mathrm{e}} \mathrm{dh}$ is stronger and more definite than ' $\overline{\mathrm{e}} \mathrm{th}$, involving predetermination in respect to a specified time. Its widest sense is that of the seasons fixed by the movements of the heavenly bodies, Gen. 1:14; Ps. 104:19. Hence also a time fixed by mutual agreement, 1 Sam. 13:8,10, or by a recognized authority, Gen. 18:14, especially the regularly recurring religious feasts of Israel, cf. Lev. 23:4, which include Sabbaths and other holy days, Lev. 23:2; Hos. 2:11(13). These are known as the $m \bar{o}^{1 a} \mathrm{~d} h \bar{e} y y^{e} h \bar{o} w \bar{a} h$, feasts of the Lord, a designation which is pre-eminently applicable to the great national feasts that drew the people from all parts of the land to the central sanctuary.

$$
\text { Yôm day. }
$$

$\mathrm{Y}$ o $\mathrm{m}$ designates both a period of twenty-four hours and that portion of the twenty-four hours which is light in distinction from that which is dark,-- "Elohim called the light y ôm," Gen. 1:5. In the account of creation y $\hat{\mathrm{m}}$ may have been employed by the narrator in its diurnal sense, though not necessarily so, inasmuch as the same writer, the "Elohist," employs the word a little further on, Gen. 5:2, in the elastic sense of a period of time indefinitely extended. This sense is also presented in the frequently recurring phrase bă y y ôm hăh $\bar{u}$, in that day, the day of Israel's redemption, foretold by the prophets and eagerly 
anticipated by an oppressed and afflicted people. With the article, hă y y ôm, it denotes the present day, to-day, Gen. 4:14. With k ŏl, in the phrase k ŏl-hăy y ôm, Ps. 42:4; 73:14, or the plural kŏl-hă y y $\overline{\mathrm{am}} \mathrm{im}, 1$ Kgs. 5:11(15), it is used in the same sense as $t \bar{a} m \hat{\imath} d h$, continually.

An idiomatic use occurs in the expression, "the day of any one," designating a day especially important or significant. Job "cursed his day," 3:1, i. e. the day of his birth ; "the day of our king," Hos. 7:5, was the coronation day; "in the day of Midian," Isa. 9:4(3), denoted the day of Midian's overthrow and slaughter; "O thou deadly wounded.... whose day is come," Ezek. 21:25(30), i. e. the day of death. A peculiar interest attaches to this word in the favorite prophetic phrase y $0 \mathrm{~m} \mathrm{y}^{\bullet} \mathrm{h} \overline{\mathrm{o}} \mathrm{w} \mathrm{a}$, the day of Jehovah, or of the Lord. Its first occurrence is in Obadiah, v. 12, "For near is the day of Jehovah upon all the nations," though it must have been in use before his time. From this date onward it becomes a stereotyped designation of the approaching political and religious crisis in the history of Israel, and of the contemporaneous nations. An examination of the phrase shows that it includes the twofold thought of judgment and redemption. It was a day of divine vengeance upon the enemies of the chosen people for their sin and oppression, but not on them exclusively ; for, contrary to the expectation of the proud and rebellious in Israel and Judah who comforted themselves with the false hope of a divine rescue, Amos exclaims, "Woe unto you that desire the day of Jehovah! Wherefore would ye have the day of Jehovah? It is darkness and not light," 5:18, and Joel $(1: 15 ; 2: 2)$ cries, "Alas for the day! for the day of Jehovah is at hand, and as destruction from Shaddai it shall come"..." a day of darkness and gloominess, a day of clouds and thick darkness." It was a day when Jehovah would visit upon his people their sins. After the darkness comes the light in the redemption of the true Israel, and its establishment upon Mount Zion as a blessed and holy remnant. God's compassion is shown at the same time to the outward world in so far as it repents and seeks salvation through Israel's God. Universal grace follows universal judgment. In this pregnant phrase, then, we discern, not the events of a day of twenty-four hours, but the transactions of the entire period of divine retribution and redemption which followed the close of Israel's probation, and which must precede the consummation of the kingdom of God. The phrase passed into the New Testament, where in the various forms "the day of the Lord," "the day of Christ," "the day of the Lord Jesus Christ," it designated his second advent at the close of the Messianic period.

\section{Tämîdh continually.}

$\mathrm{Ta} m \hat{i} d h$ is derived from an unused stem which presents the thought of spreading out, and hence $t \bar{a} \mathrm{~m} \hat{\mathrm{i}} \mathrm{dh}$ is that which is spread out, or continuity of time, unbroken, uninterrupted duration. It is most frequently used as an adverb in the sense of continually, an extension in time to which the writer or speaker sees no immediate limit. An established custom may be spoken of as $t \bar{a} m \hat{i} d h$, as Mephibosheth " did eat continually at the king's table," 2 Sam. 9:13. The ritual services connected with the tabernacle or the temple are to be observed $t \bar{a} m \hat{i} d h$, continually, because the period through which they were to be perpetuated was not limitable by human authority. Thus the shew-bread on Jehovah's table, Ex. 25: 30 ; the oil for the golden lamp, Ex. 26:20; the morning and evening sacrifice, Ex. 29:42, were to be presented through all generations. In glancing over the uses of the word, it will be seen that it refers almost exclusively to human activity, 
hence to continuity within the boundaries of human life or of national existence. The only exceptions are Deut. 11:12. "The eyes of Jehovah are upon it [the land of Canaan], $t a \bar{m} \hat{i} d h$, from the beginning of the year even unto the end of the year," and Isa. 58:11, "Jehovah shall guide thee tāmîdh." Even in these instances limits are asserted or implied. It never refers to that which has in itself the quality of endless continuance, as the permanent activities or attributes of the Divine Being.

\section{‘adh forever.}

The root meaning of this word seems to be a forthgoing, hence duration, perpetuity. It differs from $t \bar{a} \mathrm{~m} \hat{\mathrm{l}} \mathrm{dh}$ in designating continuance of being or action without assignable limits. Its predominant employment, therefore, is in the description of divine attributes or activities. Jehovah's "righteousness endureth lā'ădh," Ps. 111:3; "he retaineth not làăădh his anger," Mic. 7:18. In a single instance, Isa. 57:15, it is employed absolutely, shōke n ' $\breve{a} \mathrm{~d} h$,

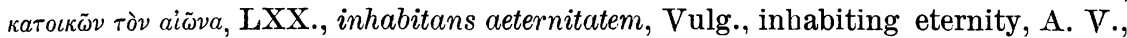
and that inhabiteth eternity, R. V. Prof. Cheyne and other modern commentators render it "dwelling forever," thus securing apparent consistency in the renderings. This translation seems hardly exact, since "forever" is not a rendering of ' $\breve{a} d h$, but of $l \bar{a}^{\prime} \breve{a} d h$, unto perpetuity, to eternity. The phrase in question seems, in harmony with the older versions, to present not merely the thought of God's unbroken existence, but it suggests the thought that he sustains an altogether different relation to time from ourselves,- that he dwells in the timeworld, ai $\omega v$, just as he dwells in the space-world, кó $\mu$ os.

The idea of endless duration is still more fully and emphatically brought out in the frequent association of ' $\breve{a} \mathrm{dh}$ with 'ôlām, in the phrase $l^{\circ} \bar{o} \mathrm{l} \hat{\mathrm{a} m}$

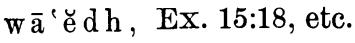

\section{'oläm forever, eternity.}

The discouraging limitations of human life led the Hebrews, as well as other peoples, early to form the idea of an unending life of illimitable existence. This thought found frequent and predominant expression in the word ' $\hat{o} l \bar{a} \mathrm{~m}$, very seldom written defectively ' $\bar{o} l \bar{a} \mathrm{~m}$. It is derived from ' $\overline{\mathrm{a}} \mathrm{l} \mathrm{a} \mathrm{m}$, to hide, which gives also the derivative t $\breve{a}^{\prime} \breve{\mathrm{e}} \mathrm{l} \breve{\mathrm{u}} \mathrm{m} \overline{\mathrm{a}} \mathrm{h}$, that which is hidden, a secret, Job 28:18; Ps. 44:22(21). Used as a time-word 'ôlām suggests a duration whose limits are hidden from human sight, hence immeasurableness, illimitableness. It describes

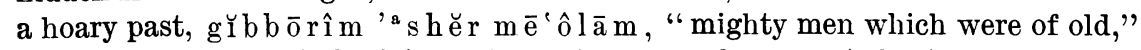
immemorably distant aborigines, Gen. 6:4, "remember $\mathrm{y}^{e} \mathrm{~m} \hat{o} \mathrm{th}$ ' $\hat{\mathrm{o}} \mathrm{l} \overline{\mathrm{a}} \mathrm{m}$, the days of the vanished past," Deut. 32:7. So also the people that dwell in Sheol seem to emerge out of a remote and timeless past, Ezek. $26: 20$; Lam. 3:6. With equal propriety this word designates also a future that, according to the speaker's point of view, may expand from a horizon more or less remote into a duration inconceivably vast. The idea of absolute limitlessness attaches itself especially to the existence of God. At Beer-sheba Abraham "called on the name of the everlasting God," 'ēl 'ôla $\mathrm{a}$, Gen. 21:33. The thought is stated more fully in the phrase $m \bar{e}^{\prime} \hat{o} l \bar{a} m w^{e} \mathfrak{a} d h-^{\prime} \hat{o} l \bar{a} m$, from eternity [past] to eternity [future] thou art God," Ps. 90:2. The same thought occurs in 1 Chron. 16:36, "Blessed be Jehovah, God of Israel, from the everlasting [past] to the everlasting [future]," m $\mathrm{n}$ $\mathrm{h} \bar{a}^{\prime} \hat{o} l \bar{a} \mathrm{~m} \mathrm{w}^{e} \mathrm{a} \breve{d} \mathrm{~h}-\mathrm{h} \bar{a}^{\prime} \hat{o} l \bar{a} \mathrm{~m}$. The A. V. renders it "world" in two instances 
only, Ps. 73:12 and Eccl. 3:11. In the former place, instead of "the ungodly who prosper in the world," we should read "being always at ease they increase in riches." In the latter instance, "He hath made everything beautiful in its time; also he hath set ' $\hat{o} l \bar{a} \mathrm{~m}$ in the heart of man," notwithstanding the disposition of Gesenius and other Hebraists to give it the meaning "world," saeculum, which it acquired in the later Hebrew, we are not justified in departing from the ordinary meaning of the word. There is not an instance in Scripture where ' $\hat{o} l \bar{a} \mathrm{~m}$ may fairly be interpreted "world." Such instances as Ps. 145:13; 106:4, which have been adduced, yield a far better sense when ' $\hat{o} l \bar{a} \mathrm{~m}$ is translated by a timeword. In the passage before us the preacher would say, that God has indeed made the course of nature and of human life attractive with beauty and delight; still he has put eternity in man's heart, and therefore man cannot find permanent contentment and satisfaction in the finite world. Anything less than the infinite and eternal, for which his spirit yearns irrepressibly, becomes in the end hateful, a vanity and vexation of spirit, 2:12 seq. He may not be able to understand the work that God doeth from the beginning to the end, nevertheless he turns wearily from the perishable works of his own hands in which there is no good, to the imperishable works of God. In the contemplation of these and in doing good man finds the joy of life, v. 12.

\title{
THE SONG OF DEBORAH-JUDGES $\mathrm{V}$.
}

\author{
By Professor Thomas Hill Rich, M. A.,
}

Cobb Divinity School, Lewiston, Me.

\section{AN INTERPRetation OF THE SONG.}

Verse 1. Deborah begins her song with an exhortation to praise Jehovah, that he has stirred the mighty in Israel to exert their might; that he has given the people heart to seek the foe.

Vs. 3-5. She would have the neighboring kings and princes listen while she extols Jehovah, the God whom Israel serves. At once addressing Jehovah, and referring to the time when he adopted Israel as his people, she makes mention of the commotions in nature attending that transaction. Thus she indicates that Israel's God has power to defend the people of his choice ; and might be expected to interpose in their time of need-as these kings and princes have just seen him do-and make his people always triumph.

Vs. 6-8. True it is, she says, that in spite of what Shamgar and Jael might do, the highways and villages of Israel were long deserted; and so continued until I, Deborah, arose, and my mother-like counsels prevailed.

But this abject condition of Israel, she says, was due to their forsaking Jehovah, their God; who therefore punished them with war and lack of courage to defend themselves with shield and spear.

Vs. 9-12. But a better day has come, and with heart turned to those who have brought it to pass-grateful both to those who gave command, and to their volunteer army-Deborah again summons to Jehovah's praise. All classes should 